NBSIR 75-967

\title{
Radiative Ignition of Some Typical Floor Covering Materials
}

Karen Den Braven

Center for Fire Research

Institute for Applied Technology

National Bureau of Standards

Washington, D. C. 20234

December 1975

Final Report

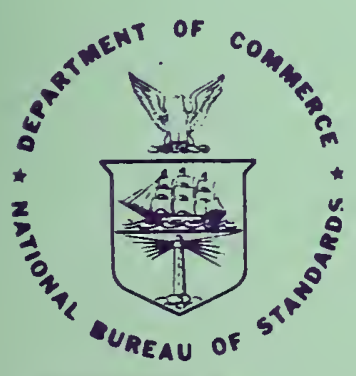

U S. DEPARTMENT OF COMMERCE

NATIONAL BUREAU OF STANDARDS 



\section{RADIATIVE IGNITION OF SOME TYPICAL FLOOR COVERING MATERIALS}

Karen Den Braven

Center for Fire Research Institute for Applied Technology National Bureau of Standards

Washington, D. C. 20234

December 1975

Final Report

U.S. DEPARTAENT OF COMMERCE, Rogers C.B. Morton, Socrotary James A. Baker, III, Under Secrotary

Dr. Betsy Ancker-Johnson, Assistant Secretary for Scionce and Technology

NATIONAL BUREAU OF STANDARDS. Emest Ambler, Acting Director 



\section{CONTENTS}

Page

LIST OF FIGURES . . . . . . . . . . . . . . . . iv

LIST OF TABLES. . . . . . . . . . . . . . . iv

Abstract. . . . . . . . . . . . . . . 1

1. INTRODUCTION. . . . . . . . . . . . . . . I 1

2. EXPERIMENT. . . . . . . . . . . . . . 2

3. DISCUSSION OF RESULT. . . . . . . . . . . . 3

4. REFERENCES. . . . . . . . . . . . . . 5 
Figure 1. Schematic of Apparatus . . . . . . . . 8

Figure 2. Ignition Delay Time $\left(t_{i g}\right)$ vs Incident Radiant Heat Flux ('q") for a white Acrylic Carpet $(\mathrm{A}-5)$. . . . . . . . . . 9

Figure 3. Ignition Delay Time $\left(t_{i g}\right)$ vs Incident Radiant Heat Flux (qُ") for $0.6 \mathrm{~cm}$ Thick Hardboard. . . . . . . . . . . 10

Figure 4. Ignition Delay Time $\left(t_{i g}\right)$ vs Incident Radiant Heat Flux (q́) for a Vinyl-Asbestos Floor Tile... . . . . . . . . . 11

Figure 5. Transient or Unsustained Ignition Time $\left(t_{i g}\right)$
vs Incident Radiant Heat Flux ( $\left.\dot{q}^{\prime \prime}\right)$ for an Aromatic Polyamide Carpet. . . . . . . . 12

Figure 6. Ignition Delay Time $\left(t_{i g}\right)$ vs Incident Radiant Heat Flux (q") for a Red Acrylic Carpet.............. . . 13

Figure 7. Ignition Delay Time $\left(t_{i g}\right)$ vs Incident Radiant Heat Flux at Various Pilot Distances for a White Acrylic Carpet... . . . . 14

\section{LIST OF TABLES}

Table 1. Materials Tested . . . . . . . . . 15

Table 2a. A Comparison of Ignition and Flashover Times for Several Floor Coverings. . . . 16

Table 2b. Material Identification Code . . . . . . 17 
RADIATIVE IGNITION OF SOME

TYPICAL FLOOR COVERING MATERIALS

\section{Karen Den Braven}

\section{Abstract}

The ignition time for some typical floor coverings was measured at varying incident radiant flux levels. A large radiant panel was used as a heat source, with a non-impinging pilot flame $1.0 \mathrm{~cm}$ above the sample as an ignition source. Each material was subjected to flux levels varying from $0.5-2.4 \mathrm{~W} / \mathrm{cm}^{2}$. Samples were $5 \mathrm{~cm}$ square, mounted horizontally below the radiant panel. A critical flux level, below which ignition did not occur, was determined for each material. No correlation was observed between the ignition time of flooring samples and the time to flashover in fullscale corridor experiments in which the same flooring materials were used.

Key words: Carpets; floor coverings; horizontal; ignition; ignition time; pilot ignition; radiant heat flux.

\section{INTRODUCTION}

Ignition experiments have been done using a large radiant panel and a non-impinging pilot diffusion flame on small samples of various floor coverings. The purpose of the experiments was to determine the ignition delay time $\left(t_{i g}\right)$ as a function of incident radiative heat flux $(\dot{q} ")$ in a low velocity (room) environment with an ambient temperature of $24 \pm 2{ }^{\circ} \mathrm{C}$. The radiant flux level ranged from the 
minimum value to cause ignition for a given material to generally $2.5 \mathrm{~W} / \mathrm{cm}^{2}$. The results from these preliminary experiments could give some indication of the ignition hazard of floor coverings. For example, these results could indicate when a room floor covering might ignite when exposed to the radiant heating of a developing fire.

\section{EXPERIMENT}

A radiant panel was oriented horizontally with the sample placed below. The samples themselves were $5 \mathrm{~cm}$ square, and were mounted in a steel box which exposed the sample surface to radiation from the radiant panel. They were kept at the surface by a $0.6 \mathrm{~cm}$ thick asbestos-cement board $\left(2,100 \mathrm{~kg} / \mathrm{m}^{3}\right)$ which was epoxied to a set of five small springs which bore against the bottom of the box. These springs promoted good contact between the asbestos-cement board and the rear face of the sample and pressed the front face of the sample against the top lip of the steel box. The distance from the radiant panel was measured to the sample surface. The pilot flame was approximately $0.7 \mathrm{~cm}$ in diameter and its lower edge was kept $1.0 \mathrm{~cm}$ above the center of the sample. The radiant panel described by Kashiwagi [1] was $38 \mathrm{~cm} \times 84 \mathrm{~cm}$ in size, and was kept at a constant temperature of around $870{ }^{\circ} \mathrm{K}$. A schematic of the apparatus is shown in figure 1. Radiant flux levels were changed by varying the distance from the sample to the panel. A heat flux meter was used to calibrate these distances and also to determine the time at which the panel temperature stabilized, after which a test was begun.

After the sample holder had been placed under the radiant panel, the sample was kept from exposure to the panel by an 
aluminum shutter. Timing with a stop watch began when the shutter was removed. The sample was then allowed to heat and ignite. Unnecessary time under the panel was kept to a minimum to avoid unwanted preheating. The gas pilot was just large enough to insure the life of the flame in the stream of hot pyrolysis gases from the samples. In most cases, gas evolution would begin shortly after exposure to the panel.

\section{DISCUSSION OF RESULT}

Many times recurrent flashes from the pilot to the sample surface would occur before ignition. In such cases the time noted was that of sustained ignition. The exception to this rule was the aromatic polyamide carpet, which would not sustain ignition. In this case, the times recorded were those at which the first flashing occurred. With this material, as well as with other samples that would not ignite, gas evolution would reach a peak, then taper off and eventually subside.

A variety of materials were chosen for the tests. The white acrylic carpet coded A-5 was chosen because of extensive testing done on flame spread for this particular type by Kashiwagi [I]. The aromatic polyamide carpet was chosen for its fire resistant nature.

Behavior of the different materials was generally similar, with the surface flashes noted with each type. The white acrylic, however, would char, then form large black bubbles on the surface. When these bubbles broke, ignition occurred (see fig. 2). However, with the tempered hardboard, there appears to be two different types of ignition: 
those in which the sample cracked and those in which no cracks occurred (see fig. 3). Cracking occurred at lower flux levels after long heating durations. The crack would ignite first, then the flame would spread over the entire sample. These cracks would often continue to smolder after extinguishment of the flame.

The vinyl-asbestos tile was also chosen as a representative floor covering that might be relatively difficult to ignite. In these tests, however, its ignition curve (see fig. 4) is very similar to that of the non-cracking hardboard. As the tile sample was heated, it tended to bulge away from the support toward the flame. However, it never came in contact with the pilot. Prior to ignition, frequent flashing was always noted. Also the pilot flame would turn shades of light blue and green from the volatile gases given off by the sample.

Results from the white acrylic carpet were the most reproducible. Separate runs at the same radiant flux level often differred by only a few seconds. The hardboard seemed the least consistent, due in part to the problem with the cracking at low flux levels. The aromatic polyamide carpet proved itself particularly difficult to ignite. Even at flux levels well above $2 \mathrm{~W} / \mathrm{cm}^{2}$ the samples would, after a few minutes, begin flashing with great frequency, but would never sustain ignition. After several minutes of this flashing it would abruptly cease, with decreased gas evolution thereafter. Thus, the curve in figure 5 records the time of flashing, as opposed to sustained ignition. Again, the flashing ignition curve is similar in form to the sustained ignition curves of the other floor coverings. 
All the materials appear to have a specific critical flux associated with them, below which ignition will not occur. For materials such as A-5 the curve (see fig. 2) appears gradually to approach an asymptote of $0.97 \mathrm{~W} / \mathrm{cm}^{2}$. For the red acrylic (see fig. 6), however, the asymptote is abruptly reached, with the graph becoming almost vertical below $1.24 \mathrm{~W} / \mathrm{cm}^{2}$. The highest flux level tested at which ignition did not occur is noted for each material on the figures. Thus, the critical ignition flux lies between the "no ignition line" and the lowest ignition flux data point. The apparent asymptote on the ignition curves yields the critical flux.

A question was raised concerning the choice of $1.0 \mathrm{~cm}$ as the distance from the pilot flame to the sample surface. It can be qualitatively assumed that the farther the pilot is from the sample the longer the ignition time. The question then was whether $1.0 \mathrm{~cm}$ was a sufficiently short distance to allow the determination of the correct minimum flux necessary for ignition. A series of tests was run to determine the effect of pilot distance on ignition time. The white acrylic $(A-5)$ was chosen because previous test results with this material proved very reproducible.

Three distances were chosen, $0.5,1.0$, and $2.0 \mathrm{~cm}$. At $<0.5 \mathrm{~cm}$ the pilot tended to impinge on the carpet surface, causing almost immediate ignition. The data for the $1.0 \mathrm{~cm}$ distance comes from the original tests (see fig. 2). The results are shown in figure 7 . Though there is some difference in ignition time between 0.5 and $1.0 \mathrm{~cm}$ at intermediate flux levels, the asymptotes are the same. As can be expected, the graph shows that $2.0 \mathrm{~cm}$ is not a sufficiently short distance for establishing the proper asymptote. Ignition times are much longer at all flux levels tested. Thus, 1.0 $\mathrm{cm}$ can be considered as an adequate distance for testing. 
As a final experiment, twelve floor covering materials used in NBS full-scale corridor fire experiments were tested in this ignition apparatus. This was undertaken to examine whether an ignition phenomenon might have been the mechanism of flashover in these full-scale tests. The flooring assembly of the ignition experiments matched in most cases the fullscale assembly configuration. The NBS corridor subfloor was 0.64 cement-asbestos board on brick which corresponds to the support block of the sample holder. Carpet underlayment was used in the ignition experiments as indicated by "/u" in table $2 \mathrm{a}$. However, samples were not bonded in the ignition experiments as indicated by " $g$ " (table 2a) for the corresponding full-scale test. Also, a plywood underlay was not used for the wood floors as was done in full-scale. The radiant flux level was fixed at $2.1 \mathrm{~W} / \mathrm{cm}^{2}$. Relative ranking given by the resultant ignition delay times did not correlate with the full-scale corridor flashover times [2]. The comparison is included as table 2. It is a striking contrast that the wool carpet with underlayment ignited in the shortest time, yet the same carpet without underlayment did not ignite at all! These results were repeated twice with excellent reproducibility; in fact, most of the ignition results in table $2 \mathrm{a}$ were reproduced twice. The fact that a correlation between ignition times and flashover times did not result, suggests that an ignition mechanism was not responsible for flashover in these corridor experiments. The mechanisms promoting flashover can be many and complex. Hence, correlation is not necessarily to be expected for corridors. Similarly, the relationship of ignition-controlled flashover to room, rather than corridor, floor coverings is a separate, and presently unresolved, question. 


\section{REFERENCES}

[1] Kashiwagi, T., Experimental Observation of Flame Spread Characteristics Over Selected Carpets, JFF/ Consumer Product Flammability, Vol. 1, 367-389 (Dec. 1974).

[2] Quintiere, J. and Huggett, C., An Evaluation of Flame Spread Test Methods for Floor Covering Materials, Nat. Bur. Stand. (U.S.), Special Publication 4ll, Fire Safety Research, Proceedings of a Symposium held at the National Bureau of Standards, August 1973, 59-89 (Nov. 1973). 

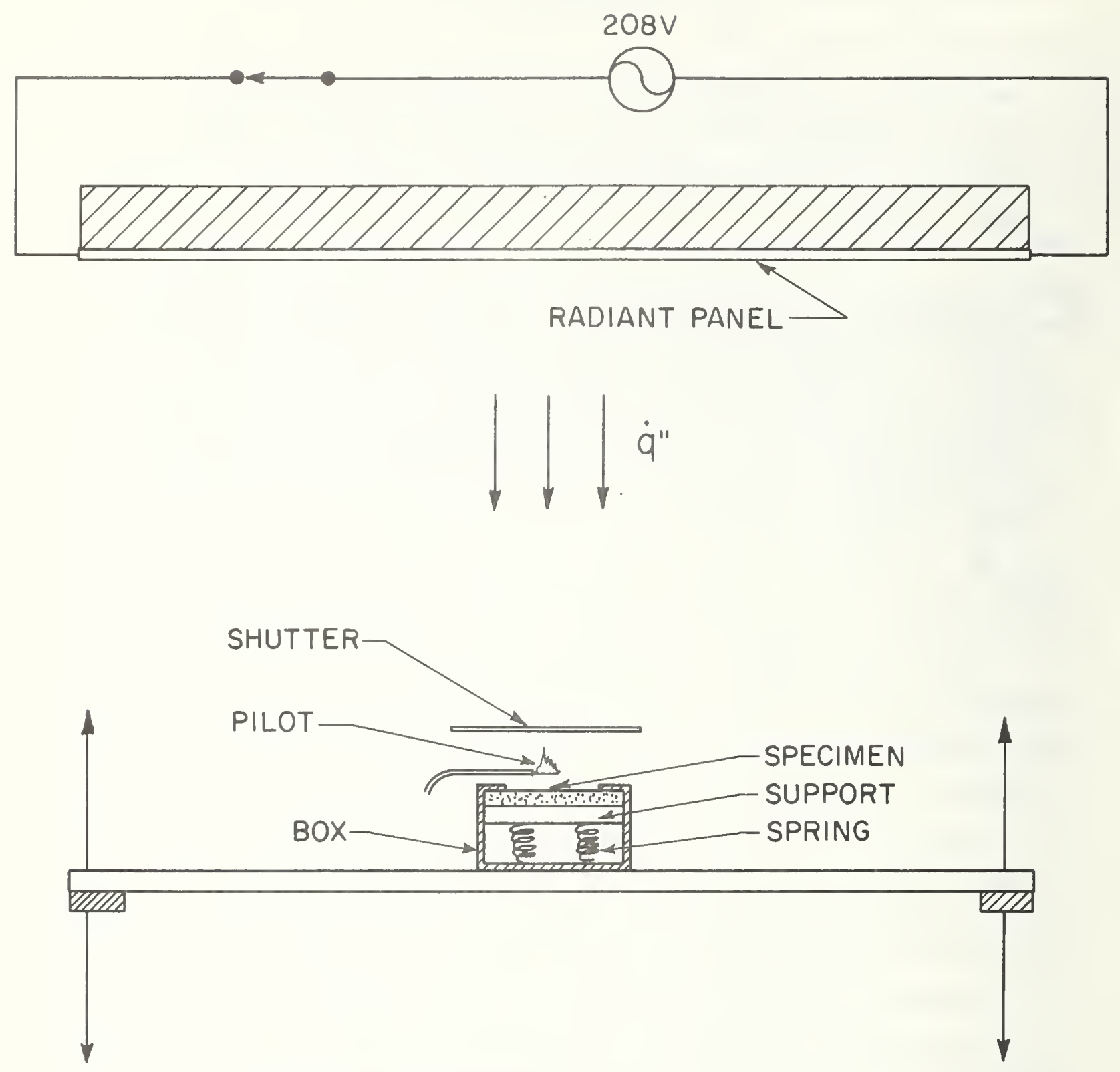

NOTE: Not to scale 


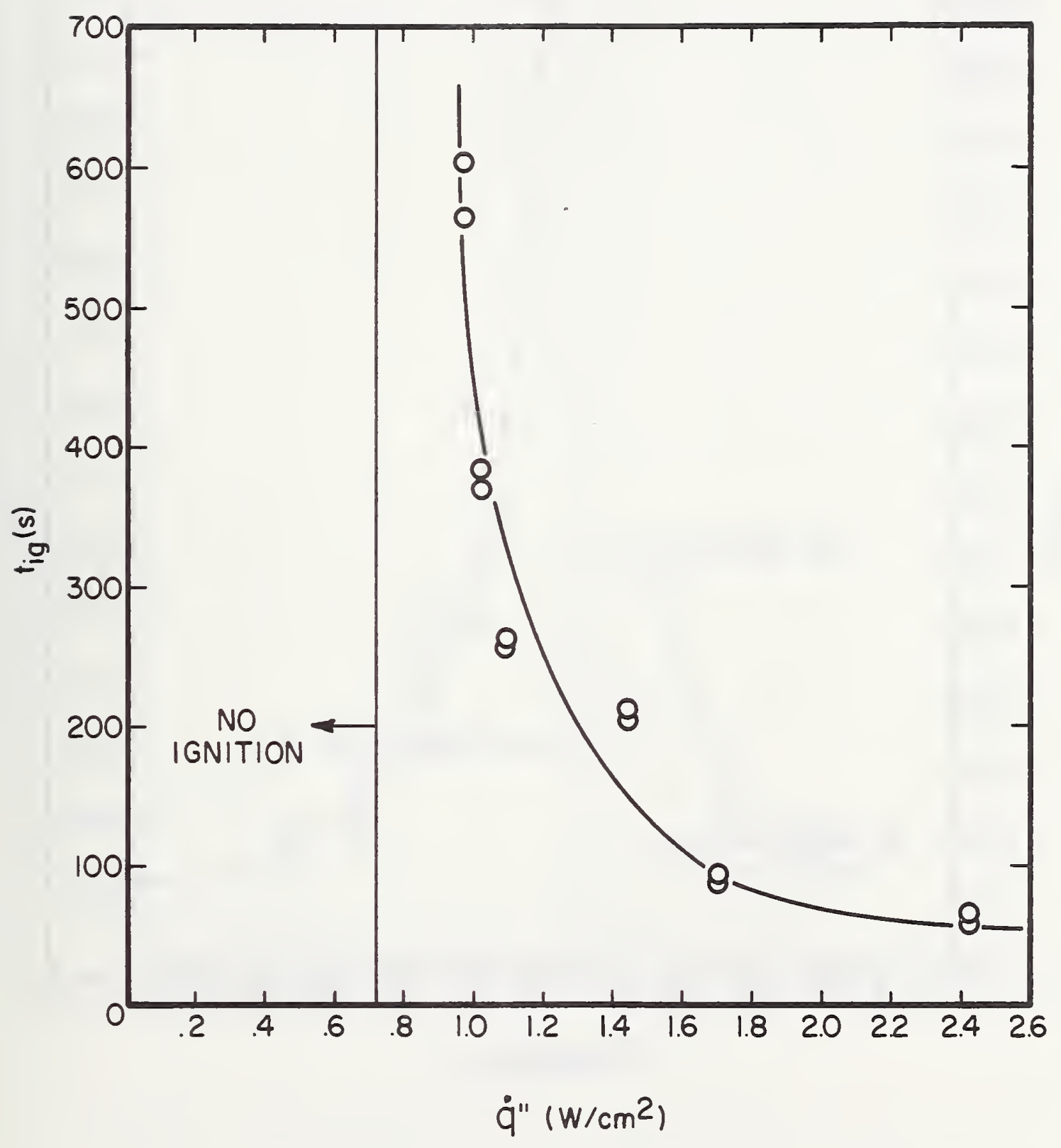

Figure 2. Ignition Delay Time $\left(t_{i g}\right)$ vs Incident Radiant Heat Flux (q") for a White Acrylic Carpet (A-5) 


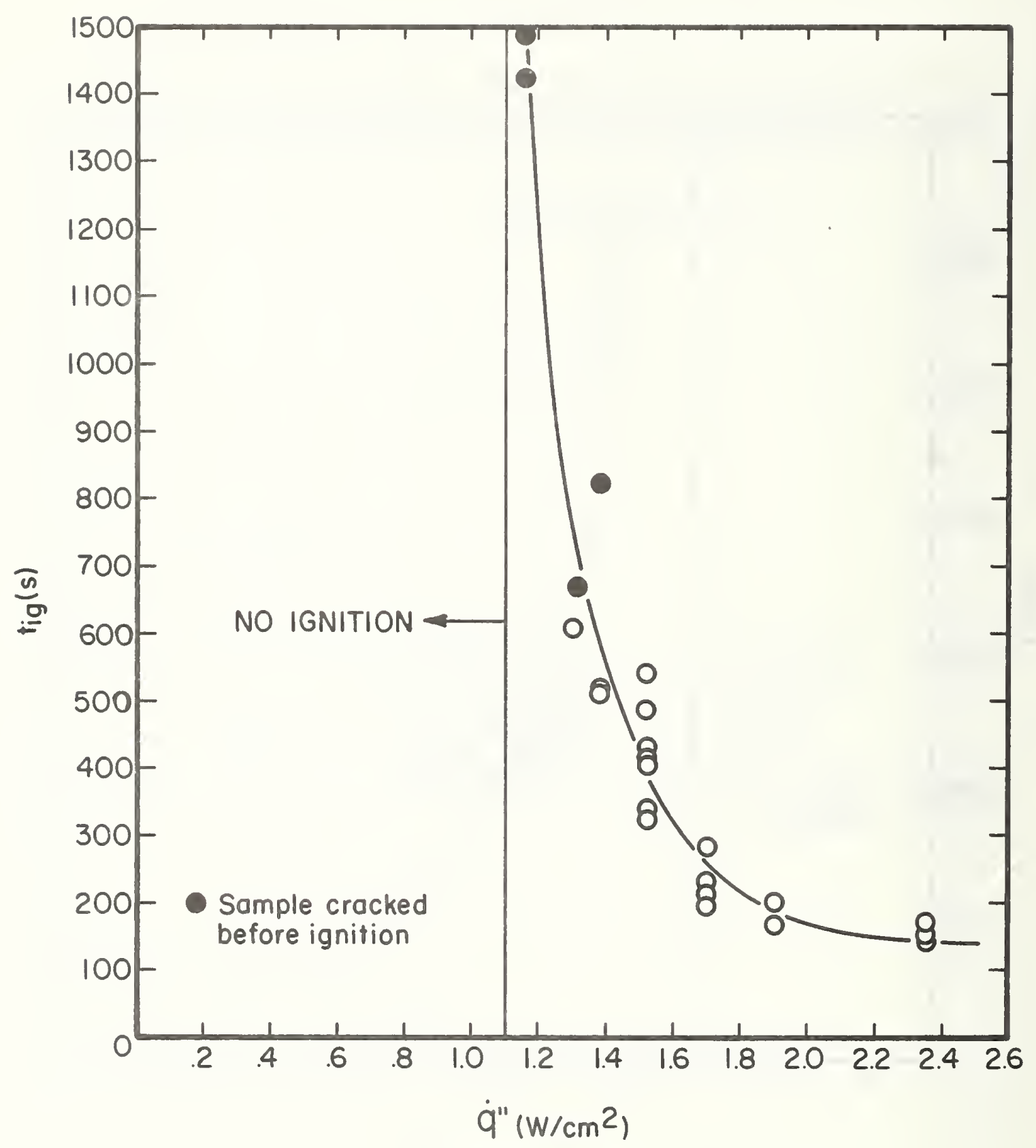

Figure 3. Ignition Delay Time $\left(t_{i g}\right)$ vs Incident Radiant Heat Flux (q") for $0.6 \mathrm{~cm}$ Thick Hardboard 


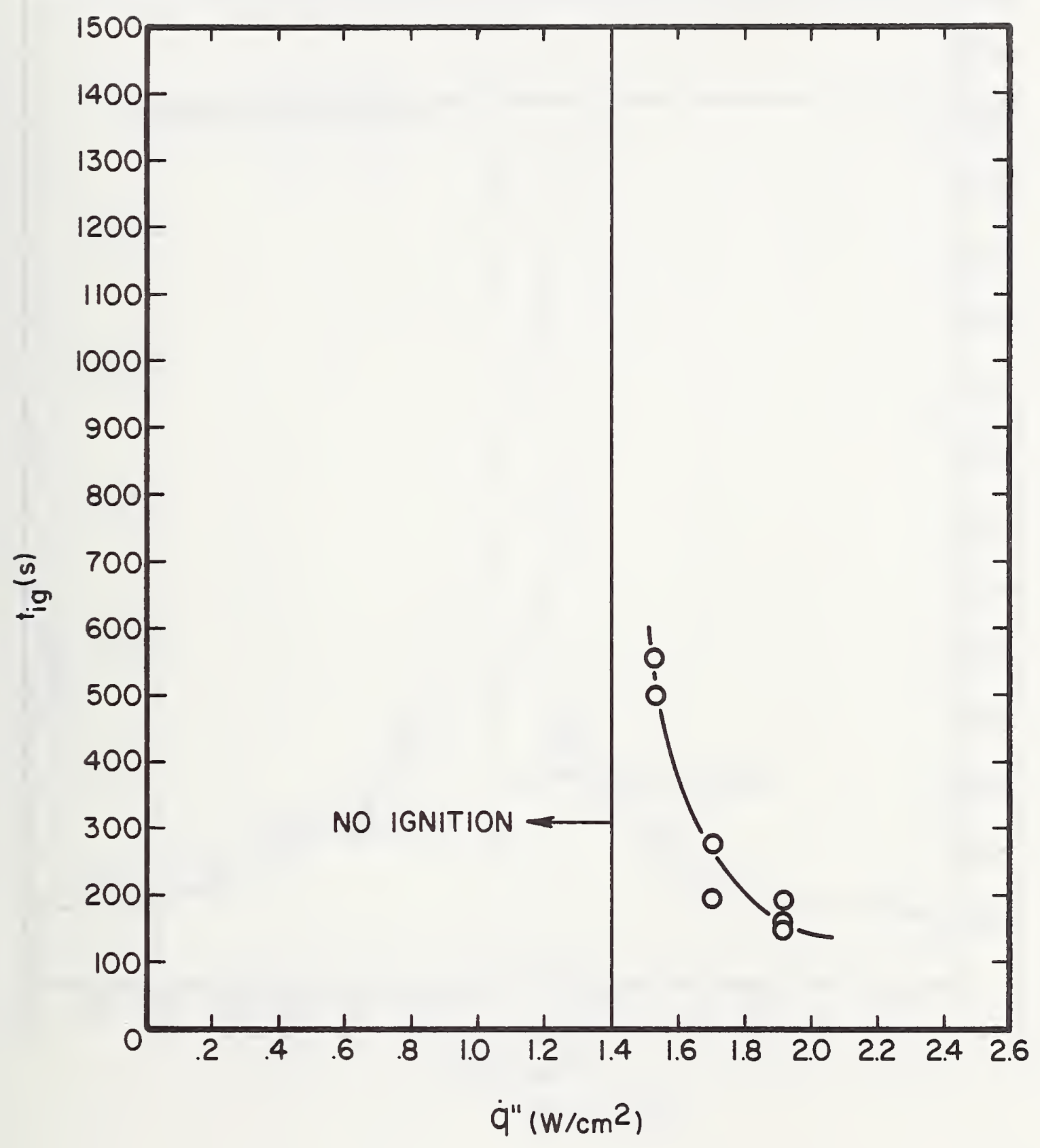

Figure 4. Ignition Delay Time $\left(t_{i g}\right)$ vs Incident Radiant Heat Flux ( $\left.\dot{q}^{\prime \prime}\right)$ for a Vinyl-Asbestos Floor Tile 


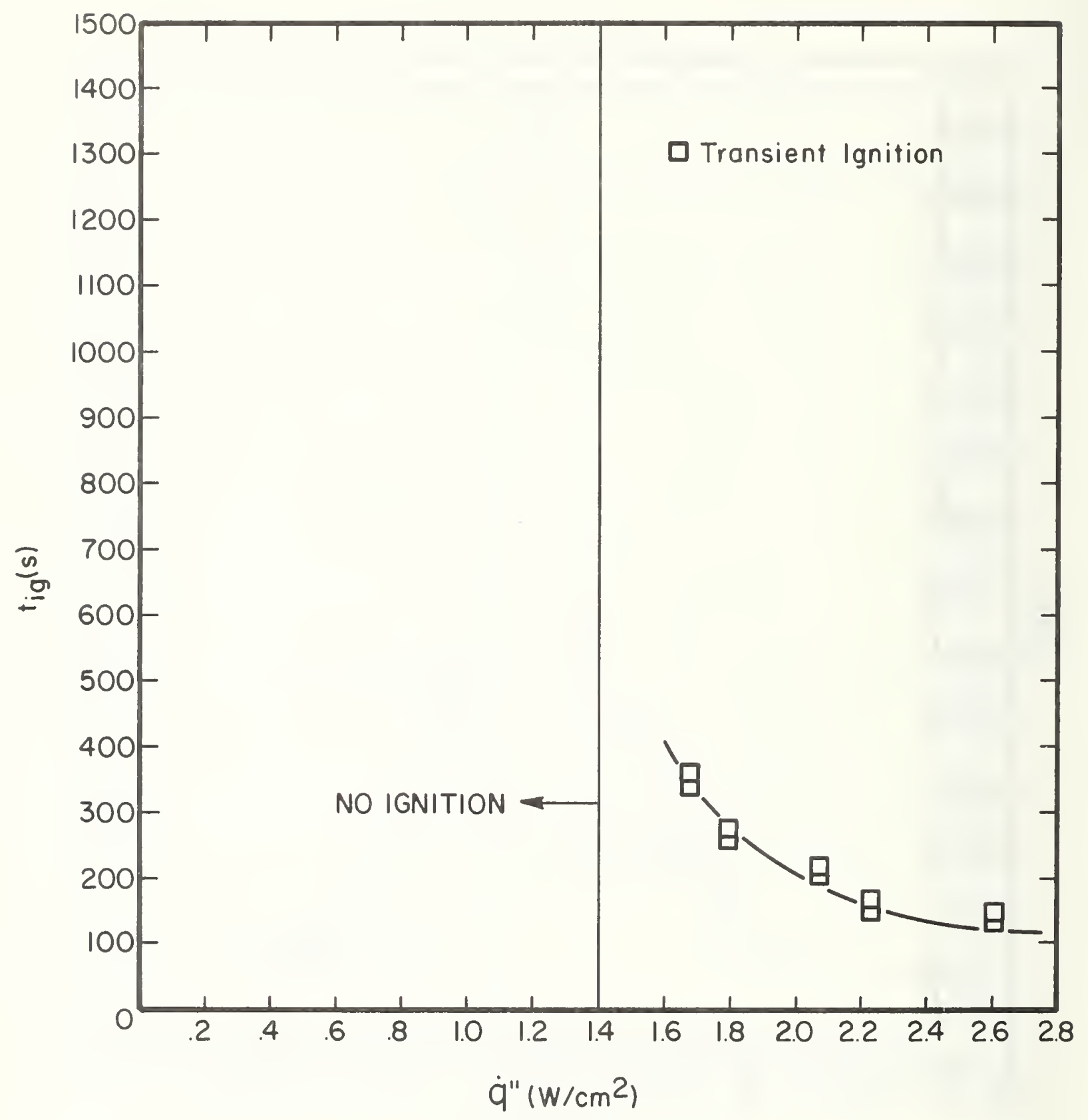

Figure 5. Transient or Unsustained Ignition Time $\left(t_{i g}\right)$ vs Incident Radiant Flux $\left(\dot{q}^{\prime \prime}\right)$ for an Aromatic Polyamide Carpet 


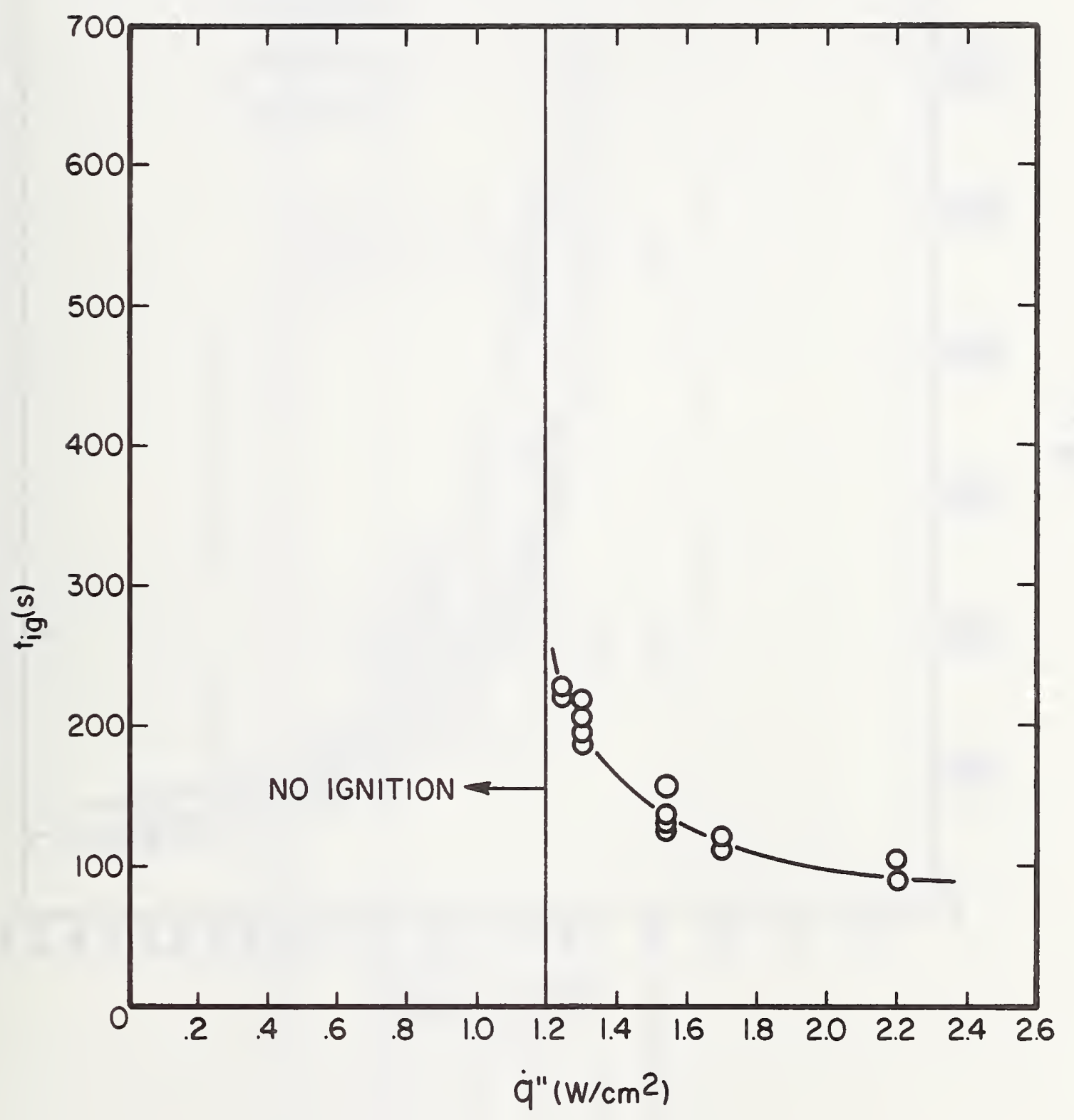

Figure 6. Ignition Delay Time $\left(t_{i g}\right)$ vs Incident Radiant Heat Flux ( $\left.\dot{q}^{\prime \prime}\right)$ for a Red Acrylic Carpet 


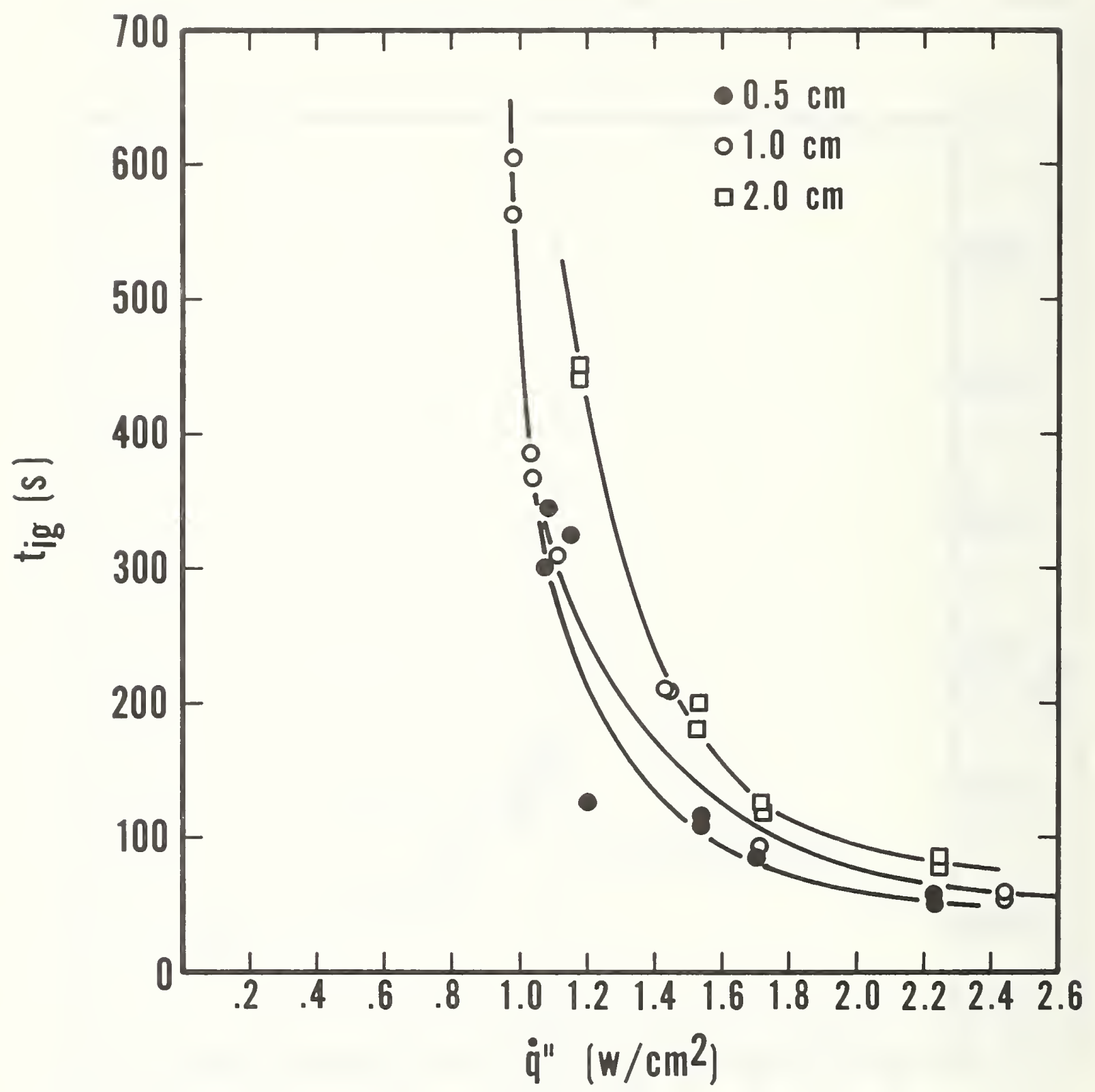

Figure 7. Ignition Delay Time $\left(t_{i g}\right)$ vs Incident Radiant Heat Flux at Various Distances for a White Acrylic Carpet 


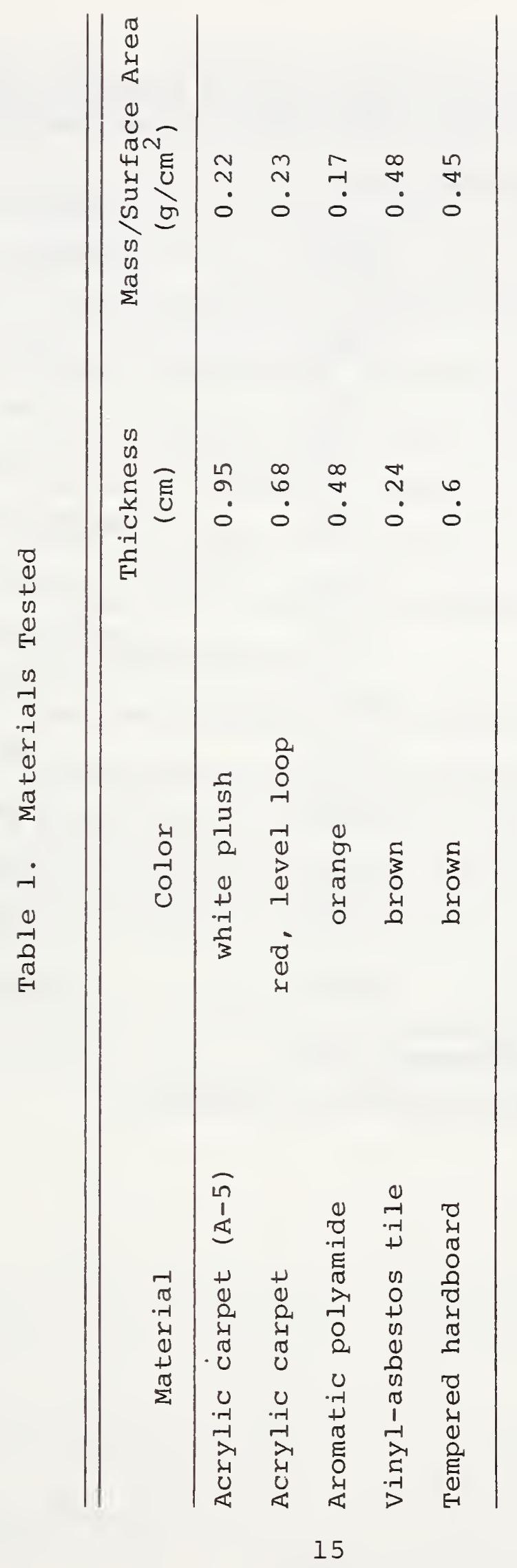


Table 2a. A Comparison of Ignition and Flashover Times for Several Floor Coverings

\begin{tabular}{lcc}
\hline Sample & $\begin{array}{c}t_{\text {ig }}^{\text {at } 2.1} \\
\text { W/cm } \\
(\mathrm{s})\end{array}$ & $\begin{array}{c}\text { NBS Corridor } \\
\text { Flashover Time* } \\
(\mathrm{s})\end{array}$ \\
\hline $\mathrm{W}-1 / \mathrm{u}$ & 40 & 460 \\
A-2/u & 53 & 342 \\
N-l-g & 88 & 840 \\
A-l & 92 & No Sustained Spread \\
A-l/u & 108 & 555 \\
R-4-g & 158 & No Sustained Spread \\
N-3/u & 277 & 440 \\
N-lF & 486 & 300 \\
RO & 1043 & 630 \\
RO-V & 1063 & 444 \\
NO & $107^{+}$ & 740 \\
W-1 & none & 312,420 \\
\hline
\end{tabular}

*From Quintiere and Huggett [2]

tunsustained ignition, start of flashing. 
Table 2b. * Material Identification Code

Code

Material

A-1 Acrylic carpet, woven level loop, $.18 \mathrm{~g} / \mathrm{cm}^{2}$

A-2 Acrylic carpet, random shear, $.23 \mathrm{~g} / \mathrm{cm}^{2}$

$\mathrm{N}-1 \mathrm{~F} \quad \mathrm{Nylon}$ carpet with integral foamback, $.30 \mathrm{~g} / \mathrm{cm}^{2}$

N-3 Nylon carpet, level loop, $.23 \mathrm{~g} / \mathrm{cm}^{2}$

NO Aromatic polyamide carpet, $0.17 \mathrm{~g} / \mathrm{cm}^{2}$

o-l-g Olefin carpet, level loop, bonded, $.18 \mathrm{~g} / \mathrm{cm}^{2}$

R-4-g Vinyl sheet, bonded, inorganic backing

RO Red oak flooring

RO-V Red oak flooring with spar varnish

u Rubberized hair-jute underlayment, $0.19 \mathrm{~g} / \mathrm{cm}^{2}$

W-1 Wool carpet, woven level loop, $.25 \mathrm{~g} / \mathrm{cm}^{2}$

*Quintiere, J. and Huggett, C. [2] p. 67 
NBS-1) $4 A$ (REV.7-73)

\begin{tabular}{|c|c|c|}
\hline $\begin{array}{l}\text { 1. PUBLIC.ATION OR RF.PORT NO. } \\
\text { NBSIR } 75-967\end{array}$ & $\begin{array}{l}\text { 2. Gov't Accession } \\
\text { No. }\end{array}$ & 3. Recipient's Accession No. \\
\hline \multirow{2}{*}{\multicolumn{2}{|c|}{$\begin{array}{l}\text { 4. TITI. AND SUBTITLE } \\
\text { Radiative Ignition of Some Typical Floor } \\
\text { Covering Materials }\end{array}$}} & $\begin{array}{l}\text { 5. Publication Date } \\
\text { December } 1975\end{array}$ \\
\hline & & 6. Performing Organization Code \\
\hline $\begin{array}{l}\text { 7. AUTIIOR(S) } \\
\text { Karen Den Braven }\end{array}$ & & 8. Performing Organ. Report No. \\
\hline \multicolumn{2}{|l|}{ 9. PERFORMING ORGANIZATION NAME AND ADDRESS } & $\begin{array}{l}\text { 10. Project/Task/Work Unit No. } \\
4915676\end{array}$ \\
\hline \multicolumn{2}{|l|}{$\begin{array}{l}\text { DEPARTMENT OF COMMERCE } \\
\text { WASHINGTON, D.C. } 20234\end{array}$} & 11. Contract/Grant No. \\
\hline \multirow{2}{*}{\multicolumn{2}{|c|}{$\begin{array}{l}\text { 12. Sponsoring Organization Name and Complete Address (Street, City, State, ZIP) } \\
\text { Same as No. } 9\end{array}$}} & $\begin{array}{l}\text { 13. Type of Report \& Period } \\
\text { Covered Final }\end{array}$ \\
\hline & & 14. Sponsoring Agency Code \\
\hline
\end{tabular}

15. SUPPLEMENTARY NOTES

16. ABSTRACT (A 200-word or less factual summary of most significant information. If document includes a significant bibliography or literature survey, mention it here.)

The ignition time for some typical floor coverings was measured at varying incident radiant flux levels. A large radiant panel was used as a heat source, with a non-impinging pilot flame $1.0 \mathrm{~cm}$ above the sample as an ignition source. Each material was subjected to flux levels varying from $0.5-2.4 \mathrm{~W} / \mathrm{cm}^{2}$. Samples were $5 \mathrm{~cm}$ square, mounted horizontally below the radiant panel. A critical flux level, below which ignition did not occur, was determined for each material. No correlation was observed between the ignition time of flooring samples and the time to flashover in full-scale corridor experiments in which the same flooring materials were used.

17. KEY WORDS (six to twelve entries; alphabetical order; capitalize only the first letter of the first key word unless a proper name; separated by semicolons)

Carpets; floor coverings; horizontal; ignition; ignition time; pilot ignition; radiant heat flux.

18. AVAILABILITY X Unimited

For Official Distribution. Do Not Release to NTIS

$\square$ Order From Sup. of Doc., U.S. Government Printing Office Washington, D.C. 20402, SD Cat. No. C13

X Order From National Technical Information Service (NTIS) Springfield, Virginia 22I5I

\begin{tabular}{|c|c|}
$\begin{array}{c}\text { 19. SECURITY CLASS } \\
\text { (THIS REPURT) }\end{array}$ & 21. NO. OF PAGES \\
UNCL ASSIFIED & 20 \\
\hline $\begin{array}{c}\text { 20. SECURITY CLASS } \\
\text { (THIS PAGE) } \\
\text { UNCLASSIFIED }\end{array}$ & $\begin{array}{c}\text { 22. Price } \\
\$ 3.50\end{array}$ \\
\hline
\end{tabular}

